Marquette University

e-Publications@Marquette

$10-1-1998$

\title{
Averroes on Psychology and the Principles of Metaphysics
}

Richard C. Taylor

Marquette University, richard.taylor@marquette.edu

Published version. Journal of the History of Philosophy, Vol. 36, No. 4 (October, 1998): 507-523. DOI. Copyright (C) 1998 Journal of the History of Philosophy, Inc. This article first appeared in Journal of the History of Philosophy 36:4 (1998), 507-523. Reprinted with permission by The Johns Hopkins University Press. 


\title{
Averroes on Psychology and the Principles of Metaphysics ${ }^{1}$
}

\author{
RICHARD G. TAYLOR
}

FIRST TRANSLATED FROM Arabic into Latin in the early thirteenth century, the philosophical works of Averroes were initially respected as valuable aids to understanding the true philosophy of Aristotle. William of Auvergne, Bishop of Paris and author of a philosophically astute theological synthesis of Greek and Arabic thought with Christian doctrine, openly expressed his appreciation with praise for Averroes. But by the mid-thirteenth century many of Averroes' teachings were under attack with his conceptions of human nature and separate immaterial intellect the subject of sharply focussed and heated argumentative assaults by Aquinas, Albert and others. ${ }^{2}$ Their arguments were not primarily theological but rather philosophical criticisms which charged that Averroes,

'Drafts of this paper were presented at a conference sponsored by the International Society for the History of Arabic and Islamic Science and Philosophy at the Smithsonian Institution in Washington, DC, March 28, 1996, and at the annual meeting of the Medieval Academy of America in Toronto, Canada, April 19, 1997. I benefited from discussions of this article with Alfred Ivry, my colleagues, David B. Twetten, Owen Goldin and Michael Wreen, and from the suggestions of two evaluators for JHP.

${ }^{2}$ This has long been recognized. "The reception of these translations of Averroes' commentaries by Christian philosophers may be described by a term currently in vogue as ambivalent. They praised him as commentator but damned him as theologian. . . Already in the thirteenth century, while he was hailed by William of Auvergne (1228-1249) as 'the most noble philosopher' (philosophus nobilissimus), by St. Thomas as 'the Commentator' (Commentator), and Dante as 'he who made the grand commentary (il gran commento),' he was decried by all of these, as well as others, for certain heretical views. Special books were written against him and time and again he was publicly condemned." H. A. Wolfson, "The Twice-Revealed Averroes," in Studies in the History of Philosophy and Religion, 2 vols., ed. Isadore Twersky and George H. Williams (Cambridge, Massachusetts: Harvard University Press, 1973), vol. 1, 371-4o 1. See 272-373. Also see Bernardo Carlos Bazán, "On 'First Averroism' and its Doctrinal Background," in Of Scholars, Savants, and their Texts: Studies in Philosophy and Religious Thought. Essays in Honor of Arthur Hyman, ed. Ruth Link-Salinger et alii (New York/Bern: Peter Lang, 1989), 9-22. For a discussion of the influence of the psychology of Averroes, see Edward Mahoney, "Sense, Intellect, and Imagination in Albert, Thomas, and Siger," in The Cambridge History of Later Medieval Philosophy, ed. Norman Kretzmann et alii (Cambridge: Cambridge University Press, 1982), chapter 3o, 6oz-622. 
particularly in his Psychology, failed to understand Aristotle and misrepresented Aristotle's thought in his confused exposition of Aristotle's Psychology. This is so well-known to us in our own day that Averroes' name has even made its way into Copi's elementary logic text as part of an exercise using a quotation from Duns Scotus in which this Islamic philosopher is called "That accursed Averroes." Scotus remarks that

... [A]ll philosophers commonly assign "rational" as the difference that properly defines man, meaning by "rational" that the intellective soul is an essential part of man.

In fact, to put it briefly, no philosopher of any note can be found to deny this except that accursed Averroes (ille maledictus Averroes) in his commentary on De anima, Bk III, where his fantastic conception, intelligible neither to himself nor to others, assumes the intellective part of man to be a sort of separate substance united to man through the medium of sense images. 3

In a general way Averroes' name has been associated with naturalistic thought labeled "Latin Averroism" which appeared to deny the personal immortality of the soul, to follow Aristotle regarding the eternity of the world, and to place the rational in priority to the religious. Not at all surprisingly, such an understanding of Averroes' thought sees him as a personification not only of religious unorthodoxy well deserving of suppression and correction in the cultural contexts of Medieval Christianity and Islam, but also of philosophical foolishness and of heresy against the Aristotelian tradition.4

Such a view of the work of Averroes, however, is in part a consequence of a failure to appreciate fully the depth of reflection which Averroes brought to Aristotelian texts and philosophical principles. His account of the relationship of philosophical Psychology and metaphysics and of how Psychology provides key principles both for the establishment of the science of Metaphysics and for the explanation of separate intellect. That account provides evidence of a sophisticated mind at work weaving from Aristotelian threads a coherent cloth of metaphysical teachings. And what provides the basis for this account is

${ }^{3}$ John Duns Scotus, Quaestiones in Lib. IV Sententiarum (Ordinatio) Dist. 43, q.2, in Opera Omnia (Lugduni: Sumptibus Laurentii Durand, 1639), vol. 10: 22, translated by Allan Wolter in Duns Scotus. Philosophical Writings (Edinburgh and London, 1962), 146-147 and quoted by Irving M. Copi and Carl Cohen in Introduction to Logic, 8th ed. (New York and London, 1990), 127. I want to thank my Marquette University colleague, Michael Wreen, for calling my attention to this passage in Copi.

4 Bonaventure has long been recognized as being among the most insightful and critical of the Latin theologians alarmed by the teachings of Averroes and his Latin admirers. See Etienne Gilson, History of Christian Philosophy in the Middle Ages (New York: Random House, 1955), 402-403. It seems doubtful that "local political infighting" was the sole or even primary reason for the suppression of philosophy which resulted in the banishment of Averroes toward the end of his life. See Oliver Leaman, Averroes and his Philosophy (Oxford: Clarendon Press, 1988), 4. Cf. Richard C. Taylor, "Personal Immortality in Averroes' Mature Philosophical Psychology," Documenti e Studi sulla Tradizione Filosofica Medievale 9 (1998) 87-110. 
nothing other than his controversial and seldom understood doctrine of the separate Material Intellect which is one for all humankind. The present article concerns that teaching on separate intellect and aims to show how Averroes can assert in his Long Commentary on the De Anima and in his Long Commentary on the Metaphysics that principles for the science of Metaphysics are established in the science of Psychology, a science which is itself a branch of Natural Philosophy or Physics.

1 .

At the beginning of chapter 1 of book VI of his Metaphysics, Aristotle states that, "We are seeking the principles and the causes of the things that are, and obviously of things qua being." 5 Setting forth a division of the sciences into practical, productive and theoretical, he explains that while the theoretical science of mathematics deals with its objects as immovable and as separable from matter, "natural science deals with things which are inseparable from matter but are not immovable." But "first science deals with things which are both separable and immovable." He goes on to assert the existence of three theoretical sciences, namely mathematics, natural science and theology, and to assert the existence of a highest science dealing with the highest genus. This is First Philosophy, which is universal in scope. But this First Philosophy will be the theoretical science of theology only if its subject matter, separate substance, can be shown to exist. As Aristotle puts it there: "If there is no substance other than those which are formed by nature, natural science will be the first science; but if there is an immovable substance, the science of this must be prior and must be first philosophy, and universal in this way, because it is first. And it will belong to this to consider being qua being-both what it is and the attributes which belong to it qua being."6

In his comment on this in the Long Commentary on the Metaphysics, Averroes explains Aristotle's reference to theology by noting that divine things are those in whose definition reference is made to God and that if there is a divine science, that science concerns what is in a separate nature. ${ }^{7}$ And he also goes on to endorse Aristotle's view that "if there were no other substance than the sensible, there would be no science prior to Natural Science." But "if there is some immobile substance, that substance is first and its science is a universal

${ }^{5}$ Metaphysics VI 1, 1025 $5^{\mathrm{b}-3}$ in The Complete Works of Aristotle. The Revised Oxford Translation, vol. 2, edited by Jonathan Barnes (Princeton: Princeton University Press, 1984).

${ }^{6}$ Ibid., VI 1, 1026 a27-32.

${ }^{7}$ Averroes Tafsîr mâ bacd al-Tabî $a h$, ed. Maurice Bouyges, S.J., vol. 2 (Beirut: Dar al-Machreq Editeurs [Imprimerie Catholique] 1967²), Book Hâ' c.2, 711-712; Aristotelis Metaphysicorum Libri XIIII cum Averrois Cordubensis in eosdem commentariis et epitome in In Aristotelis Opera Cum Averrois Commentariis, (Venice: Iunctas, 1574), vol. 8, VI c.2, f. $146 \mathrm{v} \mathrm{H-I.}$ 
science and First Philosophy." 8 Hence, Averroes clearly holds to the necessity of establishing the existence of substance which is separate and not the subject of the science of Physics or Natural Philosophy if there is to be a third theoretical science, the science which he and the tradition knew as Metaphysics. If this cannot be accomplished, First Philosophy will turn out to be Physics or Natural Philosophy. 9 Where is it established that there is such a nature? As is wellknown, Averroes rejects the approach to Metaphysics of Avicenna who takes being as divided into the necessary and the possible as a starting point. ${ }^{10}$ Instead, for Averroes, as for his master, Aristotle, it must be the science of Physics or Natural Philosophy that provides the reason or basis for the science of Metaphysics.

The search for the establishment of the subject matter of Metaphysics, then, takes us to the Physics of Aristotle and Averroes' exposition. Yet exactly how Aristotle's arguments in books VII and VIII of his Physics are to be construed is a difficult matter. The arguments of the Physics can be read as leading directly to the famous account of the divine found in Metaphysics XII, that is, the account of the necessity of the existence of an unmoved mover who is separate in existence from the world, purely actual, ultimately responsible for the motions of the heavens by way of final causality, and there characterized as a substance essentially self-thinking thought in actuality. ${ }^{11}$ Yet such a reading of the Physics of Aristotle is far from easily established, for it is not unreasonable to hold that the God of the Physics is much different from the God of the Metaphysics. Aristotle's arguments in his Physics seem to lead, not to a cause of motion which acts by way of final causality as in the Metaphysics, but rather to a first mover who is a mover by way of motion or efficient causality. Moreover, as Herbert Davidson and others have pointed out, insofar as Aristotle holds in the Physics that the eternal motion of the heavens requires infinite power and that infinite power cannot be held within a finite body, Aristotle does provide a

\footnotetext{
${ }^{8}$ Aristotle, Metaphysics VI 1, 1026a29-31. Averroes Tafsîr mâ ba'd al-Tabn ah, ed. Bouyges, Book Hâ' c.2, 7 l4; Aristotelis Metaphysicorum Libri XIIII, VI c.2, f. 147 r A.

9 In his Long Commentary on the Metaphysics Averroes follows Aristotle's lead at Metaphysics VII 11 , 1037 a $3^{-1} 7$ in calling Physics or Natural Philosophy "secondary philosophy." "It is with a view to this that we are trying to determine the nature of sensible substances, since in a sense the study of

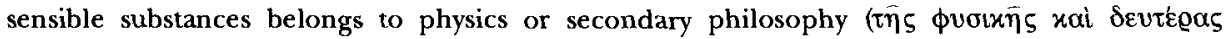
$\phi 1 \lambda$ oooфias; for the physicist must know not only about the matter but also about the substance according to the formula; this is even more essential." Barnes, Greek added. See Averroes Tafsir mâ ba'd al-Tabíah, vol.2, Book Zâ' c.39, 935-936; Aristotelis Metaphysicorum Libri XIIII, VII c.39, 192 r B-D.

${ }^{10}$ For Averroes the notion that one can immediately begin with certain concepts as the first principles of metaphysics and then proceed to their analysis, that is, as Ibn Sina does with the notion of being as necessary and possible, etc., is methodologically unsound. For a recent account of this doctrine, see L. E. Goodman, Avicenna (London \& New York: Routledge, 1 992), $61 \mathrm{ff}$.

${ }^{11}$ Metaphysics XII 7, 1072b1-13; XII 9, $1074^{\mathrm{a}}{ }_{5}-34$.
} 
proof for an "incorporeal first mover beyond the heavens." 12 Note, however, that Aristotle's conclusion is minimalist in that he does not endeavor in the Physics to give a more detailed account of the essential nature of this "god" or first mover, since Physics deals with enmattered things and their consequent attributes. Does this account satisfy the requirements of Metaphysics VI 1 for the establishment of Metaphysics as First Philosophy? It would appear to do so, for the existence of an immovable substance is established even if it is only understood through its activity as a cause of infinite power bringing about the eternal circular motion of the heavens, while its own nature as an immaterial entity remains something not fathomed in Physics.

Averroes' position on this is similar and involves the contention that the natures of the celestial bodies are altogether different from those of bodies of the sublunar realm. While sublunar bodies are subject to dissolution because they are composites of form and matter such that the matter or substratum exists in virtue of the actuality of its correlative form, the substratum of the spheres is not subject to dissolution but rather is existent in its own right without any destructive contrariety in it. ${ }^{13}$ In contrast to the matter of this

\footnotetext{
${ }^{12}$ Herbert A. Davidson, Alfarabi, Avicenna, and Averroes on Intellect (Oxford: Oxford University Press, 1992), 325 .

13 "It has also been shown that the celestial body is composed of that which moves and that which is moved, and that that which moves does not subsist in that which is moved, nor does it inhere in it, but that which moves is completely free from all matter. All this being so, would that I knew whether that which is moved, that is the celestial body, is composed of matter and form in the manner of the sublunar bodies that are moved in virtue of themselves by a first mover in them-I refer to the bodies of living beings that are moved by a soul-or whether the celestial body is simple without possessing any force at all. By force I mean a form through which the body attains a certain activity, this form being different from the already mentioned motive form which does not subsist in the body, that is, different from the form that imparts to the body infinite motion and motivity.

"We affirm that if it is accepted by us that every force in matter is finite-and it makes no difference whether this force is active or passive, that is, receptive-and if it is true, as has been shown, that the celestial body is capable of infinite movement, it follows necessarily that it is not composed of matter and form and that it is simple, that is to say, the celestial body is a simple subject for the first mover, which is its form. For everything composed of form and matter is necessarily finite in respect to its receptivity, just as it is finite in respect to moving something other than itself. Therefore, the peculiar property of that which is moved in virtue of itself, namely, the celestial body, is that its mover is not in matter and that that which is moved by this mover is simple, not composite." Averroes' De Substantia Orbis. Critical Edition of the Hebrew Text with English Translation and Commentary by Arthur Hyman (Cambridge, Massachusetts, and Jerusalem: The Medieval Academy of America and the Israeli Academy of Sciences and Humanities, 1986), 102103. Also see his Long Commentary on the Metaphysics. Averroes Tafsîr mâ ba'd al-Tabî ah, Book Hầ c.1 2 , T 1077.1-1079.10; Aristotelis Metaphysiconum Libri XIIII, VIII c.1 2, f. 22or-v E-L. The Latin omits Arabic lines 11-12 at the end. See also Averroes Tafsîr mâ baed al-Tabî ah, Book Hầ' c. 16, 1102; Aristotelis Metaphysiconum Libri XIIII, VIII c.16,f. 225 r F. Here Averroes is commenting on Aristotle, Metaphysics VIII 6, $1045 \mathrm{~b} 22-24$.

In the Long Commentary on the De Anima he remarks, "It makes no difference whether you hold that
} 
sublunar world, as Davidson puts it, "The heavens must instead be construed as a body of a completely different type, consisting in the association of a simple matter-like substratum in motion, and an independently existing immaterial form moving the substratum. The matter-like substratum exists necessarily by virtue of itself, and the form is a source of infinite power whereby the substratum moves eternally." 14 On this account of the teaching of Averroes, then, the relationship of the substratum of the sphere and the incorporeal form moving it is one of an association like that of a soul with a body albeit with the important difference that this celestial soul is not in the celestial body as a sublunar soul is in a sublunar body. ${ }^{15}$ But just what is the nature of this

the ultimate actuality generated in any individual is the subject for that intellect, namely [the actuality] through which the Material Intellect is joined [to individuals] and [that] it is from this as if a form separable from its subject with which it is conjoined, if there is such a thing, or whether you hold that this actuality is one of the powers of the soul or [one] of the powers of the body, [still] the same impossibility follows.

"For this reason one should hold the opinion that, if there are some living things whose first actuality is a substance separate from its subjects, as is thought concerning the celestial bodies, it is impossible that there be found more than one individual from one species of these. For, if from these, namely, from the same species, we find more than one individual, for instance, with regard to a body moved by the same mover, then the being of these [others] would be useless and superfluous, since the motion of these [bodies] would be owing to an intention which is the same in number." My translation from Averrois Cordubensis Commentarium Magnum in Aristotelis De Anima Libros, ed. F. Stuart Crawford (Cambridge 1953) III c. 5, 403-404. Her eafter cited as LCDA (Long Commentary on the De Anima of Aristotle). The Arabic original of this work is not extant, although there are some fragments. See A. Ben Chahida in "Iktishâf al-nașṣ al-arabî li-ahamm ajzâ' al-sharh al-kabîr li-kitâb al-nafs ta'lîf Abî al-Walîd ibn Rushd," Al-Hayât al-Thaqấiyya 35 (1985) 14 -48.

14 Davidson, 325 .

${ }_{15}$ In a recent article David Twetten summarized this doctrine as follows:

"The Physics, as Averroes reads it, concludes to no prime mover beyond that which, together with the celestial body, forms a self-moved whole. In other words, the Physics's highest mover is nothing other than the immediate mover of the first heaven, the first celestial soul. Even the infinitely powerful prime mover of Physics 8.10 in no way surpasses the mover which chapter 6 had already proved-although less properly than chapter 10-to be entirely unmoved, separate, and immaterial. For Averroes, then, there is no transition in the Physics from a celestial soul to a prior cause. Indeed, the terms 'intellect' or 'separate intellect' are nowhere used there." David B. Twetten, "Averroes on the Prime Mover Proved in the Physics," Viator. Medieval and Renaissance Studies 26 (1995): 107-134. See 132. Twetten's understanding of this 'celestial soul' is in line with Davidson's understanding of the form of the first sphere, the eternal mover which Davidson characterizes as "independent of, although associated with, the substratum of the sphere." Davidson, 326 . But Twetten puts special emphasis on the question of the nature of this 'celestial soul' or 'associated mover' as it can be understood in Physics. He questions whether this mover could reasonably be identified with any of the separate intellects functioning as final causes in the Metaphysics and most importantly whether this investigation in the science of Physics in fact is able to conclude to the existence of God for Averroes. As he poses this question, "If the Physics demonstrates God's existence, so that God is but the first celestial 'soul,' the immediate efficient mover of the primum mobile, then how can the Metaphysics conclude that God is an exclusively final cause? . . . Averroes's exposition of the Physics offers no satisfactory ... grounds for a distinction between God and the celestial soul, or for a distinction between a celestial soul and any separate intellect. "Twetten, 134. 
association? How does this association cause the celestial body to move? And just what is the nature of this separate immaterial form? The science of the soul or Psychology, a branch of Physics, is where we must turn for answers to these questions.

2 .

In the opening lines of his de Anima, Aristotle makes the following statement:

Holding as we do that, while knowledge of any kind is a thing to be honoured and prized, one kind of it may, either by reason of its greater exactness or of a higher dignity and greater wonderfulness in its objects, be more honourable and precious than another, on both accounts we should naturally be led to place in the front rank the study of the soul. The knowledge of the soul admittedly contributes greatly to the advance of truth in general, and, above all, to our understanding of Nature, for the soul is in some sense the principle of animal life. ${ }^{16}$

For Averroes in his Long Commentary on the De Anima of Aristotle, ${ }^{17}$ due to the nobility of the subject and the demonstrative power of Psychology or the science of the soul, this science "surpasses other sciences, except for divine science, ${ }^{18}<$ and so $>$ we must hold that the science of the soul comes before the other sciences; and for this reason we placed it in a position of priority among all subjects of inquiry." 19 But there is much more to the value of Psychology for Averroes.

This interesting question is beyond the scope of the present article but it appears that the answer involves the special nature of conceptualization by intellect (tasawwur bi- $-^{-} a q l$ ) as it occurs in the celestial entities. See below $27-28$, and the article cited in note 44 .

${ }^{26}$ de Anima I 1, 402a 1 - 7 Barnes.

${ }^{17}$ A later thinker, Thomas Aquinas, who seems to have had the Long Commentary on the De Anima by Averroes open on his desk when composing his own Sentencia LibriDe Anima, remarks that Aristotle's statement that psychology "contributes greatly to the advance of truth in general" is because in First Philosophy or Metaphysics "we are able to come to knowledge of divine things and of the highest causes only in virtue of what we are able to grasp first from the power of intellect." It contributes as well, Aquinas writes, to moral philosophy since "we cannot have a complete grasp of moral science unless we know the powers of the soul, and it is consequent upon this that the Philosopher in the Ethics attributed any given virtues to the diverse potencies of the soul." Sentencia Libri De Anima in Opera Omnia Iussi Leonis XIII P.M. Edita (Rome: Commissio Leonina; Paris: Librairie Philosophique J. Vrin, 1984) 5b-6a. These remarks by Aquinas about the power of intellect and "moral science" result from his study of the corresponding comments of Averroes in the latter's Long Commentary on the De Anima. Also see Themistius, In Libros Aristotelis De Anima Paraphrasis, ed. R. Heinze (Berlin 1899) [Commentaria in Aristotelem Graeca, vol. V] 1.24-2.6; An Arabic Translation of Themistius' Commentary on Aristotle's De Anima, edited by M. C. Lyons (Columbia, South Carolina, and Oxford, England, 1973), 1.10-3.8; Latin: Themistius. Commentaire sur le Traité de l'Ame d'Aristote. Traduction de Guillaume de Moerbeke, G. Verbeke, ed. (Paris \& Louvain, 1957) 2-3; and Themistius, On Aristotle's On the Soul, tr. Robert B. Todd (Ithaca, NY: Cornell University Press, 1996), 15-16. The position of Aquinas is obvious enough, for our natural intellectual powers enable us ultimately to come to an understanding of God, according to him.

${ }^{18}$ That is, metaphysics.

${ }^{19}$ LCDA, I c. 1, 4. My translation. 
You should be aware that the science of the soul $\{5\}$ is found to be helpful to the other sciences in three ways. First, inasmuch as it is part of that science, ${ }^{20}$ indeed the noblest of its parts-and this is the relationship it has to natural science. For living things are the noblest of generable and corruptible bodies, but the soul is nobler than all <else $>$ in living things. Secondly, because it supplies more principles for more sciences, for example, for moral science-that is, < the science $>$ of governing states-and for divine science. For from this science moral science gets the ultimate end of human beings considered as human beings and the knowledge of what their substance is. The metaphysician $^{21}$ gets from it the substance of his subject. For here <in the science of the soul $>$ it will be explained that the separate forms are intelligences, and also many other things concerning the knowledge of states consequent upon intelligence considered as intelligence and intellect. And thirdly, it is generally helpful and enables the acquisition of confirmation regarding first principles, since from $<$ this science $>$ we acquire knowledge of the first causes of propositions, and knowledge of anything through its cause is more certain than $<$ knowledge $>$ only of its own being. ${ }^{22}$

Thus, Psychology helps us understand the power of soul in living things. It also supplies principles for several sciences, for moral science which is a branch of politics by making known human nature and its end, and also for Metaphysics for which it provides an understanding of the nature of intellect and separate intelligence. And, third, Psychology provides an understanding of human epistemological powers and functions.

For Averroes, it is Psychology which is responsible for supplying key principles for the establishment of the science of Metaphysics, by establishing in a way different from that of Physics that there exist separate forms and that these separately existing forms are intellectual in nature. It also is able to contribute to an understanding of the natures of the celestial bodies and their motions. What Averroes has in mind is the science of Psychology's establishment of the existence of the Agent Intellect and of the existence of the Material Intellect as separately existing substances.

The Material Intellect is defined as that which is in potency all the intentions of universal material forms and is not any of the beings in act before it thinks [any of them]. Since that is the definition of the Material Intellect, it is evident that in its own case it differs from prime matter in this respect: it is in potency all the intentions $\left\{_{3} 88\right\}$ of the universal material forms, while prime matter is in potency all those sensibles forms, not something which knows or discerns. And the reason why that nature is something which discerns and knows [distinguens et cognoscens] while prime matter neither thinks nor discerns, is because prime matter receives diverse forms, namely individual and particular forms, while this [nature] receives universal forms. From this it is

${ }^{20}$ That is, natural science.

${ }^{21}$ Divinus, the masculine of the adjective, surely reflects the Arabic al-ilâhi probably for al-ilm al-ilâh $\hat{\imath}$, "divine science." The Latin translator seems to have misunderstood al-ilâhî as "theologian" or "metaphysician," as I have chosen to render it here.

${ }^{22}$ LCDA, I c.2, 4-5. My translation. 
apparent that that nature is not a this, nor a body nor a power in a body. For, if this were so, then it would receive forms according to their diversity and particularity; and if this were so, then the forms existing in it would be intelligible in potency, and thus it would not discern the nature of the forms inasmuch as they are forms, ${ }^{23}$ as it is a disposition in relation to individual forms, be they spiritual or corporeal. For this reason, if that nature which is called the intellect receives forms, it must receive forms by another mode of reception than that by which those matters receive the forms whose determination by matter is the determination of prime matter in them. And for this reason it is not necessary that it be of the genus of those matters in which the form is enclosed, nor that it be prime matter itself. Since, if this were so, then the reception in these would be of the same genus; for the diversity of the received nature causes the diversity of the nature of the recipient. This, therefore, moves Aristotle to set forth this nature which is other than the nature of matter, other than the nature of form, and other than the nature of the composite. ${ }^{24}$

The Material Intellect has a certain potency in it insofar as it is able to have in it the intelligible forms of material things of the world in an immaterial way such that what we call knowledge of the universal is present in the intellect. When a form is in act in a particular material thing in the physical world, it exists in a material way as a particular and as such it is intelligible only in potency. That is, for it to be intelligible in act, it needs an intellect to grasp it as intelligible, it has to come to exist in an intellect as intelligible in accord with the nature of that intellect. The need for an immaterial reception of universal forms in knowing requires that what receives them be a separate intellect and yet be something which is capable of reception, that is, have a potency for the reception of immaterial forms. These intelligibles in act in the separate Material Intellect are the referents for the notions expressed by us in universal propositions of science. ${ }^{25}$

Averroes' assertion of the necessity of the existence of this separate Material Intellect is a position he came to late in life after long years of struggle over the issue of the intellect. ${ }^{26}$ His mature account follows in part from two central philosophical propositions resulting from his study of the tradition. First, as we have seen above, if the reception of an intelligible in act were to come about as a reception into a this or particular individual, what is received would be something else, that is, something which is not an intelligible in act but rather an

23 It would not grasp the natures of the forms in a way which would be consonant with scientific knowledge; that is, it would not be able to grasp them qua universal.

${ }^{24}$ LCDA, III c.5, $387-388$. My translation.

${ }_{25}$ This is one of the topics of discussion in Richard C. Taylor, "Remarks on Cogitatio in Averroes' Commentarium Magnum in Aristotelis De Anima Libros," forthcoming in Averroes and the Aristotelian Tradition: Sources, Constitution and Reception of the Philosophy of Ibn Rushd (I I $26-1$ 198), Jan A. Aertsen and Gerhard Endress, eds. (Cologne, 1998).

${ }^{26}$ Davidson gives an account of the many developments in Averroes' thought on the Material Intellect as he moved toward his mature teaching in that topic. See Davidson, 258-298. 
intelligible in potency. But in order to understand, that is, to have the intelligible in act in it, the Material Intellect cannot be a body or a power in a body since that would make it a this. ${ }^{27}$ Secondly, if the intelligible in act were in many intellects, the intelligible in act would be many intelligibles in act, not one; but the intelligible in act must be one so that there is a single intelligible which is common referent for individuals forming propositions of science, so that science is possible. ${ }^{28} \mathrm{~A}$ plurality of material intellects, then, is impossible. The material intellect has to exist as a single, separate immaterial being of an intellectual sort, not as some particular material individual. This single material intellect is shared by all human beings and is that in virtue of which they are called rational. ${ }^{29}$

In his comment to text 5 in Book III of the De Anima, Averroes remarks that the investigation into the nature of intellect yields an understanding of the material intellect as intellect and yet as having a receptive potency within it. Explaining his doctrine by analogy, he states that just

as sensible being is divided into form and matter, intelligible being must be divided into things similar to these two, namely into something similar to form and into something similar to matter. This is [something] necessarily present in every separate intelligence

${ }^{27}$ The sense in which the Material Intellect is not 'a this' has to do with the fact that it is not a member of a species properly speaking, since it is its own species. This is discussed in my article cited in note 29 .

28 "That way we posited the essence of the Material Intellect solves all the questions resulting from our holding that the intellect is one and many. For, if the thing understood in me and in you were one in every way, it would happen, that when I would know some intelligible, you would also know it, and many other impossible things. If we assert it to be many, then it would happen that the thing thought in me and in you would be one in species and two in individual [number]. In this way the thing understood will have a thing understood and so it proceeds into infinity. Thus, it will be impossible for a student to learn from a teacher unless the knowledge which is in the teacher is a power generating and creating the knowledge which is in the student, in the way in which one fire generates another $\left\{4^{12}\right\}$ fire similar to it in species, which is impossible. That what is known is the same in the teacher and the student in this way caused Plato to believe that learning is recollection. Since, then, we asserted that the intelligible thing which is in me and in you is many in subject insofar as it is true, namely the forms of the imagination, and one in the subject through which it is a being of the intellect (namely the Material Intellect), those questions are completely resolved." LCDA, III c.5, 411-412. My translation. This text of Averroes is derivative upon Themistius, Heinze, 104.1-14; Lyons, 189.2-15; Verbeke, 234-236; and Todd, tr., 129 . Averroes also found this infinite regress argument in Ibn Bâjjah's Risâlat Ittiṣâl al-aqul bi-l-insân, "Treatise on the Conjoining of the Intellect with Man." See Miguel Asín Palacios, "Tratado de Avempace sobre la Unión del intelecto con el Hombre," Al-Andalus 7 (1942): 1 - 47, section 8, Arabic Text $14-$ 15. Spanish translation, 32-33. Also see Vincent Laguardère. "L'Epître d'Ibn Bâjja sur la conjunction de l'intellect avec l'esprit humain," Revue des Etudes Islamiques 49 (1981): 175-196; see 187 .

${ }^{29}$ These two important philosophical propositions are discussed with reference to the thought of Albertus Magnus and Thomas Aquinas and their critique of Averroes by Lawrence Dewan, O.P., in "St. Albert, St. Thomas, and Knowledge," American Catholic Philosophical Quarterly 7o (1995): $121-$ 135. These propositions and their importance for the epistemology of Averroes are discussed in my article, "Remarks on Averroes's Epistemology and its Critique by Aquinas," for thcoming in Thomistic Papers VII. Medieval Masters: Essays in Memory of Msgnr. E.A. Synan, R.E. Houser, ed. (Houston, 1998). 
which thinks something else. And if not, then there would be no multiplicity $\{410\}$ in separate forms. And it was already explained in first philosophy that there is no form absolutely free of potency except the First Form which understands nothing outside Itself. $3^{\circ}$ Its essence is Its quiddity (essentia eius est quiditas eius). Other forms, however, are in some way different in quiddity and essence. ${ }^{31}$ If it were not for this genus of beings which we have come to know in the science of the soul, we could not understand multiplicity in separate things, to the extent that, unless we know here the nature of the intellect, we cannot know that the separate moving powers ought to be intellects. ${ }^{32}$

That is, this division in intellectual entities of what is analogous to form and of what is analogous to matter, or of act and potency, is discovered in Psychology. It is then used as a principle in understanding the natures of all the immaterial intelligences. Potency must be present in any separate intelligence which is capable of knowing anything outside itself. For insofar as it is an intelligence with itself as its object, it need have no potency. But insofar as it is in potency for knowing something other than its own essence or nature, namely the First Cause which is the final cause of all, it must have a certain "materiality" or potency for receiving a form other than its own from outside itself as it strives to understand the First Cause. While essentially active without potentiality for any change within them, the immaterial intelligences must nevertheless be in a relation of knowing vis à vis the First Cause. As such, for them there is less than complete and perfect unity of essence and quiddity.

3 .

The establishment of separate entity in Natural Philosophy or Physics allowed for the certification of the science of Metaphysics. Now the determination of

${ }^{30}$ This "First Form" is God for Averroes. The separate substances or intelligences are distinguished from one another in virtue of their potency for knowledge, a certain "materiality" found in each which is sufficient to allow their distinction from one another and to make reasonable the assertion that there is a multiplicity of separate substances, according to Averroes. This potency for knowledge, in particular, for knowledge of God, is the active power for intellectual understanding present in each separate immaterial substance other than God. Also see n. $4^{8}$.

${ }^{31}$ God alone is pure actuality, while other separate intellects have some potency in them. For Averroes the First is pure actuality, fa-inna-hu ficlun mahdun, Averroes Tafsîr mâ bac $d$ al-Tabrich, ed. Maurice Bouyges, S.J., vols. 3-4 (Beirut: Imprimerie Catholique, 1948), Book Lâm C.37, 1599.7. (The Latin translation omits this phrase. Cf. Aristotelis Metaphysicomum Libri XIIII, XII c.37, f.31 $9 v$ GH.) While the precise meaning of the phrase, essentia eius est quiditas eius, cannot be determined in a definitive way with out consultation of the original Arabic now lost, one can conjecture that the sense seems to be that the very self ( $d h a t i-h i^{*}$ ?) of God is fully and completely identical with his essential nature or what he is (mâhiyati-hi*?). God is the First Form in the hierarchy of separate intelligences as well as "the intelligence moving the outermost sphere" of the universe. Davidson, $25^{6 .}$

${ }^{32}$ LCDA, III C.5, 409-410. My translation. In this, then, lies the reason why the study of the soul is more worthy and more noble than other studies and why it should precede others: we understand the nature of intellect first through understanding the nature of intellect present in ourselves and only when something of that understanding has been achieved can there be any understanding of intellect in higher beings. 
the existence of separate intellect in Psychology allows for the conclusion that separate intellect is immaterial actuality and separate from the body in existence.33 It further allows for the understanding of how potency can be present in an immaterial intellect. But does it also allow us to conclude that "the separate moving powers" from the Physics "ought to be intellects," as Averroes remarks in the passage from De Anima III c. 5 ? Averroes certainly seems to think so.

This was unknown to many modern thinkers to the extent that they denied what Aristotle says in the eleventh book of the First Philosophy, that the separate forms moving the bodies must be in accord with the number of celestial bodies. 34 To this extent knowledge of the soul is necessary for knowledge of First Philosophy. ${ }^{35}$ And that receptive intellect must think the intellect which is in act. For, while it thinks material forms, it is more befitting that it think immaterial forms. And what it thinks among separate forms, for example, the Agent Intellect, does not impede it from thinking material forms. ${ }^{36}$

What Psychology does by means of the discovery of the separate agent and material intellects is to supply Metaphysics with important principles for the understanding of the conclusions of Natural Philosophy. Now the movers of the heavens, the separate intellectual souls or intellects, can be understood as different in essence from one another in virtue of differences in their levels of actuality and potency, something reflected in the different movements they cause in the heavens. Only the "First Form" or God is to be understood as pure intellectual actuality completely free of potency. 37

Such is the position of Averroes in his Long Commentary on the Metaphysics of Aristotle as well. There he remarks:

From this it is fully clear that these celestial bodies are alive and that among the powers of soul they have only intellect and the power of desire, i.e. [intellect] which causes motion in place. This is perhaps evident from what $I$ say, for it has been explained in the eighth book of the Physics that what causes motion belonging to the celestial bodies is not in matter and is a separate form. And it was explained in the De Anima that the separate forms are intellect. So, consequently, this mover is an intellect and is a mover insofar as it is an agent of motion and insofar as it is the end of motion..$^{8}$

${ }^{33}$ See Ibn Rushd's Metaphysics. A Translation with Introduction of Ibn Rushd's Commentary on Aristotle's Metaphysics, Book Lam (Leiden: E.J.Brill, 1984), by Charles Genequand, introduction, 36.

34 Metaphysics XII 8, 1073 a26-38.

${ }_{35}$ Cf. above, $22-23$ and n. 21 .

${ }^{36}$ LCDA, III c.5, 410. My translation.

37 See notes 30 and 31 .

${ }^{8}$ Averroes Tafsîr mâ ba d al-Tabñ $a h$, Book Lâm c. $3^{6}, 1593-4$. My translation. Cf. Latin, Aristotelis Metaphysicomum Libri XIIII, XII c.36, f. 318 rv F-G. Cf. Genequand, 149 : "From that, it appears in all clarity that celestial bodies have souls and that of the powers of the soul, they have only the intellect and the faculty of desire, I mean (the faculty) that imparts to them local motion. This appears from what I say: it has been explained in the eighth book of the Physics that the mover of 
Now we need to note that this conclusion does not strictly follow from what has been set forth here. As Charles Genequand points out in the introduction to his translation of Averroes' commentary on Aristotle's Book Lambda of the Metaphysics, "Combining indications drawn from the eighth book of the Physics and the third of the de Anima, Ibn Rushd tries to prove that the first mover is itself an intellect. The argument," continues Genequand, "is not quite convincing because what the de Anima shows is that the intellect is a separate form, not that any separate form is an intellect as Ibn Rushd says $\left(1593,14^{-1594,3) . " 39}\right.$ That is to say, the syllogism is not complete according to Genequand who believes the argument fails. That the mover is a separately existing immaterial actuality does not mean without further explanation that it must be an intellect, as happens in the argument of the De Anima where instead the argument moves from intellectual operations to the necessity of intellect being separate. This conclusion, however, can be drawn on the basis of an additional premise or assumption. Where are we to find the needed principle?

The reduction of oưi $\alpha$ to form and actuality in Metaphysics Zeta and Eta makes it clear that being is the actuality of form and intelligibility for Aristotle and for Averroes. $4^{\circ}$ Consequently, the argument of the Physics to a separate associated mover as an immaterial actuality is an argument to a being whose nature is form. As such, this immaterial actuality is a being and an intelligible object or form..$^{1}$ Now, in the case of immaterial intelligible objects, the $D e$ Anima has shown for Averroes that a separate intelligible object, insofar as it is actually intelligible, must exist in an intellect. Hence, it is not enough to conclude that there exists a separate intelligible object; rather, it must be concluded that an intelligible form existing as a separate actuality must in its very nature be existent in an intellect. This understanding is confirmed in the commentary on book Lambda of the Metaphysics where Averroes remarks:

Since conceptualization by intellect, which is an activity of intellect, is the intellect itself and the intellect is the intelligible itself according to what has been explained in the $D e$

these celestial bodies is without matter and a separate form, and in the De Anima that the separate forms are intellect. It follows that this mover is an intellect and that it is a mover insofar as it is the agent of motion and the end of motion."

39 Genequand, introduction, 36 .

$4^{\circ}$ In these books Aristotle traces the actuality of substance to form. The account of an existing thing which is given by its differences is one of its form and actuality. Metaphysics VIII 2, 1043a 1921. The cause of actuality in a composite thing is the form. See Averroes Tafsîr mâ bat $a l$-Tabî́ $a h$, Book Hâ' c.7, 1055 ; Aristotelis Metaphysicomum Libri XIIII, VIII c.7, f. $215 \mathrm{v} \mathrm{K}$. And forms which are not actualities of matter have being in their own right, not dependent upon anything else. These are the separate intelligences which are linked with the celestial bodies as their 'souls.' It is in this way that Averroes interprets Metaphysics VIII 6, 1045b22-24. See Averroes Tafsîr mâ bac d al-Tabí $a h$, Book Hâ' c. 16, 1102; Aristotelis Metaphysicorum Libri XIIII, VIII c.16, f. 225 r F.

${ }^{4}$ It certainly is not an unintelligible form or a non-being or privation. 
Anima, he said "The intellect is from the intelligible," meaning that the intellect in its essence and substance is only from the intelligible. $4^{2}$

Later Averroes explains that there are two sorts of intelligibles, the intelligibles of matter which are intelligible in relation to something else (namely, a knower in virtue of which these potential intelligibles become actually intelligible) and the intelligibles of the forms which are understood in their own right. These forms which are intelligible in themselves are substantial and are simple. And by simple here is meant that the form is free of matter and is not a composite. 43 Hence, an existing separate form as intelligible is an intelligible in act not dependent in its intelligibility upon a relation to something else. As such it is then an intelligible for itself and so it is also intelligent or an intellect in its own nature. Hence, contrary to the belief of Genequand, Averroes' argument is complete. Any actually existing separate form must be an intellect.

What about the celestial bodies and their relationship to their associated intellects? As Averroes understands Aristotle, the celestial bodies can only equivocally be said to have matter and soul because our use of those notions is based upon our experience in the sublunar realm where soul gives actuality to matter and the two principles make up one entity. Analogies based on what is learned from the science of Psychology have only limited value. In the case of celestial bodies, the body is not properly speaking matter actualized, that is, animated by separate principle, soul. Rather, the celestial bodies which we perceive in the heavens are immediately substantially existent per se and eternal since they have matters which do not have potency for substantial change. Celestial bodies move eternally and so have desire, but they do not have sense perception and do not have imagination and the cogitative power as do sublunar rational animals, that is, as do human beings. As Gerhard Endress puts it, for Averroes "the senses and the organs of sense-perception exist only in mortal animals, 'for the sake of preservation.' But the relation of the heavens to their principles of existence and movement is different from the relation between bodies and souls in the sublunary world, making it possible to forego the intermediary of imagination postulated by Avicenna." 44 Thus, each

$4^{2}$ Averroes Tafsîrmâba dal-Tabíah, Book Lâm c.37, 160o; Aristotelis Metaphysicorum Libri XIIII, XII c.37, f. 319 v H-I. Cf. Genequand, 151 : "Since the intellectual representation which is the activity of the intellect is the intellect itself and the intellect is the intelligible as has been shown in the de Anima, [Aristotle] says: 'the intellect comes from the intelligible', meaning: the intellect in itself and in its essence comes from the intelligible."

43 Averroes Tafsîr mâ ba'd al-Tabi ah, Book Lâm c.37, 1602-3; Aristotelis Metaphysicorum Libri XIIII, XII c. 37 , f. $3^{2}$ or A-C; Genequand, 152-153. In the LCDA Averroes remarks that "it is universally necessary in regard to intellect that that which is intelligible in act be intellect in act. ..." III c. $3^{6}$, 480. My translation.

44 Gerhard Endress, "Averroes' De Caelo, Ibn Rushd's Cosmology in his Commentaries on Aristotle's On the Heavens," Arabic Sciences and Philosophy 6 (1995): 9-49. See 33. 
of the eternally moving celestial bodies has associated with it a separate intellectual soul which is fully immaterial. By means of its association, the celestial body moves out of desire which is intellectual in nature, that is, by contemplative desire aroused by conceptualization by intellect (tasawwur bi-l- ${ }^{c} a q l$ ) of intelligibles.45 And, as we have seen, since the motion of the celestial body is eternal and necessary, according to Aristotle and Averroes, that which makes the motion to occur, separate intellect, must also exist eternally and must have an immaterial and imperishable nature as the form of the celestial body. $4^{6}$ This sort of exposition draws upon the science of soul or Psychology, insofar as it uses philosophical Psychology's understanding of desire, of conceptualization by intellect, and of corporeal human beings' linkage to separate intellect in conceptualization by intellect in order to understand the association of separate intellects with eternally moving celestial bodies.

\section{4.}

The purpose of this article has been to explain how it is that Averroes can assert in his Long Commentary on the De Anima and in his Long Commentary on the Metaphysics that principles of the science of Metaphysics are established in the science of Psychology, a science which is itself a branch of Natural Philosophy or Physics. We began with a consideration of the requirements for the assertion of the existence of a science of First Philosophy as Metaphysics in Book VI chapter 1 of Aristotle's Metaphysics. There it was held that Natural Philosophy would be First Philosophy if it could not be established that there exists separate or immaterial being. Next we understood Averroes to have proved the existence of an immaterial separate form as cause of the motion of the celestial substratum. This was sufficient to satisfy the needs expressed by Metaphysics VI 1 for the existence of an immaterial entity, and allowed that there is a universal science of being qua being which deals with things beyond those of Physics, namely the science of Metaphysics. Yet the nature of this immaterial form was not clear from the argument of the Physics. It was here that Averroes understands the science of Psychology to make an important contribution to the principles of Metaphysics. It is in Psychology that human intellectual understanding is studied and found to require the existence of the separate Agent Intellect for the account of the coming to be of knowledge as that knowledge manifests itself in human beings. In this, then, intellect and separate being are established as one, that is, it is shown on the basis of the analysis of human Psychology that intellect must exist and that this intellect must be separate

45 See the insightful and comprehensive account of the issue of celestial bodies and soulintellects in the thought of Averroes by Endress in the article cited in note 44 .

$4^{6}$ Endress, 37 . 
from the human being in existence. Moreover, it is also established on the basis of the analysis of human knowing that there exists potency in those things called intellect, thanks to the argument for the existence of the Material Intellect. These key contributions from Psychology to the principles of the science of Metaphysics were explicitly recognized by Averroes in book Lâm of his Commentary on the Metaphysics of Aristotle.

Perhaps the greatest value of this undertaking, however, is to clarify in some small way the understanding of Averroes concerning the interrelationship of the sciences of Physics, Metaphysics and Psychology. In light of the role played by Psychology in establishing principles for Metaphysics, a number of otherwise seemingly non-Aristotelian doctrines can now be seen in an Aristotelian context. One such doctrine is the plurality and hierarchy of separate intelligences or intellects discussed in Aristotle and Averroes. Aristotle never provided a sufficient account regarding the natures of the plurality of separate intellects or forms in Metaphysics XII. Certainly in the context of Aristotle's thought there, it is impossible to conceive of these pure forms and pure actualities as having any potency at all. Rather, each was a self-contained monad and only by reference to the motion it caused and by an argument from analogy could Aristotle put one of these intellects first as the highest god.47

For Averroes, however, the intellects are ranked by differences in their potentiality, not potentiality in being, but potentiality in knowing. $4^{8}$ That such potentiality existed in some way in separate intellects Averroes might have taken as a given principle or assumption if he were more a follower of the Neoplatonic tradition. In that tradition as reflected in the Arabic materials derived from texts of Plotinus and Proclus, lower intellects are illuminated by higher intellects in a species of participation. The very possibility of being receptive to illumination indicates some sort of potentiality. 49 But for Averroes

47 Aristotle's doctrine, complex and difficult, is dependent on his understanding of goodness and unity. See John M. Rist, The Mind of Aristotle (Toronto: University of Toronto Press, 1989 ), $173-177$ and $236-240$.

$4^{8}$ "For it seems that the cause of the plurality of the separate intellects is the difference in their natures, by which they receive the knowledge they gain of the First Principle and which acquire from the First Principle a unity which by itself is one single act, but which becomes many through the plurality of the recipients, just as there are many deputies under the power of a king and many arts under one art." Averroes' Tahafut al-Tahafut (The Incoherence of the Incoherence) translated by Simon Van Den Bergh (London: Luzac \& Co., 1 969), 154-155. Arabic text: Averroès. Tahafot at-tahafot, ed. Maurice Bouyges, S.J., (Beirut: Imprimerie Catholique, 1930), 160.

49 The notion of potency in an immaterial intellect is reflected in a way in the Plotinian doctrine of the emanation of Being from the One and its, as it were, ontologically subsequent, fulfillment as Intellect. See, e.g., A. H. Armstrong, "Plotinus," in The Cambridge History of Later Greek and Early Medieval Philosophy (Cambridge: Cambridge University Press, 1 967), 241-242. Also see Jean Trouillard, "La Genèse l'hylémorphisme selon Proclus," Dialogue 6 (1 967-68): 1- 17 . Regarding the Arabic materials derivative upon the work of Plotinus and Proclus, see Maroun Aouad, "La 
the assumption of philosophical doxa or tradition does not constitute philosophical proof. Rather, he argued for his similar position on the basis of understandings of intellect demonstrated in Aristotelian Physics, Psychology and Metaphysics. That is to say, his account of the natures and hierarchy of separate intellects is not Neoplatonic but Aristotelian. And in the course of constructing his argument he insisted on the importance of the role of human rationality and the investigation of it in the establishment of principles of the science of Metaphysics. These principles are established in his exposition of his controversial and difficult doctrine of the separate Material Intellect, a doctrine philosophically argued by him using Aristotelian philosophical principles.

Marquette University

Théologie d'Aristote et Autres Textes du Plotinus Arabus," in Dictionnaire des Philosophes Antiques, ed. Richard Goulet (Paris: Editions du Centre National de la Recherche Scientifique, 1989), 541-59o; Gerhard Endress, Proclus Arabus. ZwanzigAbschnitte ausderInstitutio Theologica in arabischer Übersetzung (Wiesbaden-Beyrouth: F. Steiner Verlag, 1973); and F. W. Zimmermann, "The Origins of the

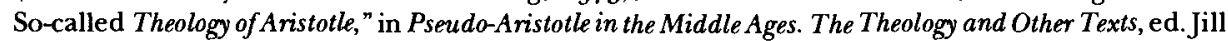
Kraye, W. F. Ryan and C. B. Schmitt (London: The Warburg Institute, 1986), $110-240$. Proposition 5 of the Liber de causis mentions the diffusion of the light of the First Cause upon things below it. This part of Proposition 5 does not come from Proclus' Elements of Theology Proposition 123, but rather is derivative upon notions found in the Plotiniana Arabica. See the discussion in Richard C. Taylor, The Liber de causis (Kalam fi mahd al-khair): A Study of Medieval Neoplatonism (Doctoral Dissertation, University of Toronto, 1981), 372. For the doctrine in the Plotiniana Arabica, see, for example, Abdurrahman Badawi, Aflutin 'inda-l- arab (Kuwait, 1977, 3rd printing), 62.1-4; translation by Geoffrey Lewis, who prepared the English translation found in Plotini Opera II, ed. Paul Henry and Hans-Rudolf Schwyzer (Paris \& Bruxelles, 1959) $3^{83}$. For additional texts, see Taylor, The Liber de causis, 372. 